\title{
Predation on newly settled bivalves by deposit-feeding amphipods: a Baltic Sea case study
}

\author{
Gunilla Ejdung ${ }^{1,2, *}$, Ragnar Elmgren ${ }^{2}$ \\ ${ }^{1}$ Department of Zoology and ${ }^{2}$ Department of Systems Ecology, Stockholm University, S-106 91 Stockholm, Sweden
}

\begin{abstract}
In the Baltic Sea, predation on postlarvae of the infaunal clam Macoma balthica by adults of the 2 most abundant deposit-feeding amphipods, Monoporeia affinis and Pontoporeia femorata, has been considered to be a crucial factor in determining the bivalve's recruitment success. The functional response of adult $M$. affinis to postlarvae of the bivalve was shown in laboratory experiments to be type IIl-like, with no levelling off of the number of prey consumed per predator within the postlarval densities tested. Densities included were higher than the highest reported from habitats where both species occur together, In laboratory experiments, adults of $P$. femorata were also shown to kill $M$. balthica postlarvae. In neither amphipod species did adults select among sizes of newly settled $M$. balthica. Juvenile $M$. affinis were likewise found to kill $M$. balthica postlarvae. Our results, and a recent field study, confirm the effect of the amphipods on $M$. balthica postlarvae and their role in controlling bivalve recruitment in Baltic soft sediments. They also support the idea that interactions among juveniles of macrofauna may affect the recruitment success of many benthic species and therefore be important in structuring benthic communities.
\end{abstract}

KEY WORDS: Predation Juvenile-juvenile interaction. Adult-juvenile interaction Monoporeia affinis - Pontoporeia femorata Macoma balthica - Postlarvae

\section{INTRODUCTION}

Among factors affecting the structure of benthic communities are the supply of settling larvae (Woodin et al. 1995) and factors affecting their planktonic growth and survival. After larval settlement, benthic communities are further structured by interactions among juvenile and adult macrofauna and meiofauna (Elmgren et al. 1986, Watzin 1986, Ejdung \& Bonsdorff 1992, Osman et al. 1992, Osman \& Whitlatch 1995, Hunt \& Scheibling 1997), as visualised in conceptual models by Ankar (1977), Bell \& Coull (1980), and Uitto \& Sarvala (1990). However, interactions within the large group of juvenile macrofauna has largely been overlooked when discussing mechanisms structuring these communities. Although juvenile macrofauna soon outgrow the threat from meiofauna, danger still remains from macrofauna, both adults and the often far more abundant juveniles.

-Address for correspondence: Department of Systems Ecology, Stockholm University, S-106 91 Stockholm, Sweden.

E-mail: gunilla@system.ecology.su.se
Deposit feeders use organic material from detritus, micro-organisms and meiofauna (Lopez \& Levinton. 1987), and may supplement these by predation on temporary meiofauna, e.g. recently settled bivalves (Elmgren et al. 1986). Even if relatively unimportant in terms of ingested carbon, such supplementation may provide essential nutrients in short supply, e.g. polyunsaturated fatty acids (Turunen \& Pekkarinen 1990). Timing, settling intensity and recruitment success varies between years (Bonsdorff et al. 1995). On occasion settling greatly increases the density of postlarvae, resulting in high abundances of potential prey, although often for a short time only (Ankar 1980, Bonsdorff et al. 1995). The number of prey consumed per predator as a function of prey density can be described as the functional response of the predator (Holling 1959). This is the first study of the functional response of early post-settlement mortality in soft-bottom habitats, more specifically for a macrofaunal deposit feeder preying on newly settled, meiofauna-sized bivalve postlarvae.

In the northwestern Baltic proper, 200 to $300 \mu \mathrm{m}$ long larvae of the bivalve Macoma balthica (L.) settle in late 
June to early July (Ankar 1980) on shallow to ca $40 \mathrm{~m}$ deep soft bottoms (Ólafsson \& Elmgren 1997, pers. obs.). Then, at the plantigrade stage (Baker \& Mann 1997), the larvae inhabit the uppermost millimetres of the sediment (Caddy 1969). Together, the bivalve and the 6 to $12 \mathrm{~mm}$ long deposit-feeding pontoporeiid amphipods Monoporeia affinis (Lindström) (syn. Pontoporeia affinis Lindström; see Bousfield 1989) and Pontoporeia femorata Kröyer make up the bulk of the macrobenthic abundance and biomass (Ankar \& Elmgren 1976. Cederwall 1990). M. affinis is found below $9 \mathrm{~m}$ depth in the area (Cederwall 1990), and on deeper mud bottoms below about $30 \mathrm{~m}$ the amphipods cooccur. $P$. femorata tends to occupy the deeper strata, and $M$. affinis the uppermost centimetres of the sediment (Hill \& Elmgren 1987). Both species feed mainly on surface sediment (Lopez \& Elmgren 1989).

Young Monoporeia affinis are released in March/ April (Sarvala 1986) and grow rapidly in June and July (Cederwall 1977, Uitto \& Sarvala 1991). Lopez \& Levinton (1987) suggested that deposit feeders are food limited most of the year. This seems to hold for $M$. affinis and Pontoporeia femorata in our investigation area (Elmgren 1978), where food is scarce, except following the sedimentation of the spring bloom (Elmgren 1978), the period during which the amphipods grow rapidly (Cederwall 1977) and build up lipid stores for overwintering and reproduction (Hill et al. 1992). The energy used by the amphipods seems to derive mainly from detrital carbon (Uitto \& Sarvala 1991, Lehtonen 1996).

From field data, Hessle (1924) and Segerstråle (1960) concluded that recruitment of Macoma balthica was prevented in areas densely populated by Monoporeia affinis and Pontoporela femorata. Segerstråle (1962) suggested that $M$. affinis (formerly Pontoporeia affinis) could ingest the newly settled bivalves, and tested this experimentally, using the mainly hard-bottom-living Mytilus edulis. He concluded that $M$. affinis may affect bivalve survival, and named this idea the 'MacomaPontoporeia theory' (Segerstråle 1965). The first experimental test of the theory actually using $M$. balthica postlarvae was performed by Elmgren et al. (1986). They demonstrated that adult $M$. affinis were able to kill and most likely also eat newly settled postlarvae of $M$. balthica, and the predicted rapid reduction after the peak in density of settling bivalves was recently confirmed in a field study (Ólafsson \& Elmgren 1997). The question of whether juvenile $M$. affinis and adults of the other common amphipod in the area, $P$. femorata, can also kill newly settled $M$. balthica postlarvae remained. Segerstråle (1962) believed that adult $P$. femorata had the same effect as $M$. affinis on $M$. balthica postlarvae, but doubted that amphipods of either species smaller than $6 \mathrm{~mm}$ could eat newly settled M. balthica (Segerstråle 1973).
In this study we present the first measurements of the functional response of a basically deposit-feeding amphipod feeding on a newly settled bivalve, namely of adult Monoporeia affinis feeding on Macoma balthica postlarvae. We further test whether juvenile $M$. affinis and adult Pontoporeia femorata also kill and presumably consume newly settled $M$. balthica postlarvae.

\section{MATERIAL AND METHODS}

Study site and procedure. This study was performed in 1990 and 1995 at the Asko Laboratory $\left(58^{\circ} 49^{\prime} \mathrm{N}, 17^{\circ} 38^{\prime} \mathrm{E}\right)$, on the coast of the northwestern Baltic Sea proper. The natural abundance of the amphipods varies greatly in this area, due to differences in bottom topography (Hessle 1924). In the Askö area (22 to $54 \mathrm{~m}$ depth, 1972 to 1993) Elmgren \& Larsson (1997) reported up to 4000 Monoporeia affinis $\mathrm{m}^{-2}$, with a corresponding abundance for Pontoporeia femorata of up to $2000 \mathrm{~m}^{-2}$, but more than $3000 P$. femorata $\mathrm{m}^{-2}$ have been recorded in the Baltic (Järvekülg 1973). The abundance of young-of-theyear $(0+) M$. affinis is high in March/April, when they leave the marsupium, and may reach over $10000 \mathrm{~m}^{-2}$ (Sarvala \& Uitto 1991). In the Askö area settlement of Macoma balthica led to peak postlarval densities of $80000 \mathrm{~m}^{-2}$ at $10 \mathrm{~m}$ depth (Ankar 1980), and of $65000 \mathrm{~m}^{2}$ at a $37 \mathrm{~m}$ deep station (Olafsson \& Elmgren 1997), while densities of up to $300000 \mathrm{~m}^{-2}$ have been reported from the Finnish Aland archipelago (6 to $8 \mathrm{~m}$ depth, medium-fine sand; Bonsdorff et al. 1995). Salinity at $10 \mathrm{~m}$ depth in the Askö area is about 6.5, and at 45 to $50 \mathrm{~m}$ depth about 7

Sediment and specimens were collected close to the Askö Laboratory with a benthic sled (Blomquist \& Lundgren 1996), amphipods and sediment from 30 to $40 \mathrm{~m}$ depth, and postlarval Macoma balthica from 4 to $16 \mathrm{~m}$. The fine muddy sediment used was the natural sediment of the amphipods. This sediment was sieved through a $100 \mu \mathrm{m}$ mesh, and had a loss on ignition of $5 \%$ in 1990 and of $2 \%$ in $1995 . M$. balthica that passed through a $500 \mu \mathrm{m}$ mesh and were retained on a $100 \mu \mathrm{m}$ mesh were concentrated according to Elmgren et al. (1986), and picked in batches of 50 in 1990 and 5 in 1995. All $M$. balthica postlarvae encountered had a maximum length of $\geq 200 \mu \mathrm{m}$. Amphipods were picked in batches of 10 adult Monoporeia affinis (1+), 20 juvenile $M$. affinis $(0+)$ or 3 adult Pontoporeia femorata $(1+)$, and kept without food for $2 \mathrm{~d}$. Before the start of the experiments, amphipods and bivalves were inspected under a stereo-microscope, and damaged individuals replaced. Batches of bivalves and amphipods were randomly chosen and added to the experi- 
mental aquaria in the appropriate abundances for each treatment. Bivalves were always added at least an hour before the amphipods, and not until the sediment had settled and the water above the sediment was clear.

Statistics and models. Data were analysed using Statistica 5 for PC. Variance homogeneity was tested according to Cochran (balanced treatments) or Bartlett (unbalanced treatments). To obtain variance homogeneity, some data were square root transformed number of postlarvae killed, functional response experiment) or arcsine square root transformed (for proportions). A 1 -factor ANOVA $(\alpha=0.05)$ was used to test for differences between/among treatments. Significant results were followed by the Tukey test for unequal $\mathrm{N}$. All values followed by a \pm value are mean \pm standard error of mean

The theoretically most interesting differences between types of functional response are found at low prey densities. The functional response can be determined on the basis of the shape of the proportional mortality curve (Lipcius \& Hines 1986, Eggleston 1990). The type II functional response shows proportionally higher mortality at lower prey densities, type IIl is characterised by proportionally lower mortality at lower densities, and type I by strictly proportional mortality (Hassell 1978). A 1-factor ANOVA was used to distinguish between these types of functional response (Eggleston 1990). In order to further characterise the type of the functional response, the type II model $y=$ $b x /(x+c)$ and the type III model $y=b x^{\beta} /\left(x^{\beta}+c\right)$ were fitted, where $y=$ Macoma balthica mortality, $x=$ initial density of $M$. balthica, $b=$ maximum feeding rate, $c=$ density of $M$. balthica generating half maximum feeding, and $\beta=$ the parameter associated with the form of the response curve; $\beta=2$ generates a type III curve (Real 1979).

Experimental conditions. The experiments with adult or juvenile Monoporeia affinis in 1990 were run for 15 d, and with adult Pontoporeia femorata in 1995 for $19 \mathrm{~d}$. A faint green light gave a $17 \mathrm{~h}$ light: $7 \mathrm{~h}$ dark cycle. The aquaria were supplied with sea water (ca 1 l $\mathrm{h}^{-1}$ aquarium $^{-1}$ ) from $16 \mathrm{~m}$ depth. During the $1990 \mathrm{ex}-$ periments the water had a temperature of $5.4 \pm 0.1^{\circ} \mathrm{C}$ $(\mathrm{n}=16)$, and a salinity of 6.6 , and in 1995 temperature and salinity were $5.0 \pm 0.1^{\circ} \mathrm{C}(n=14)$, and 6.2. In 1990 , the $2 \mathrm{l}$ glass aquaria of Elmgren et al. (1986) were filled with sieved sediment to a depth of ca 4 to $5 \mathrm{~cm}$, giving a sediment area of $104 \mathrm{~cm}^{2}$. The $2 \mathrm{l}$ aquaria were placed randomly in water-filled troughs and connected to the seawater system. In 1995 sieved sediment was added to small $105 \mathrm{ml}$ aquaria, to a depth of $\mathrm{ca} 2 \mathrm{~cm}$, giving a sediment area of $13 \mathrm{~cm}^{2}$ The aquaria were placed in a temperature-regulated room, and supplied with sea water from the seawater system.
Functional response of adult Monoporeia affinis to Macoma balthica postlarvae. This experiment assessed the feeding response of adult $M$. affinis over a range of M. balthica (length $337 \pm 6 \mu \mathrm{m}$ ) densities, between 2400 and $153000 \mathrm{~m}^{-2}$ (25 to 1600 aquarium $^{-1}$; see Table 1). Forty $M$. affinis $\left(3800 \mathrm{~m}^{-2}, 1+\right.$; length $6.8 \pm$ $0.1 \mathrm{~mm}$ ) were used per aquarium. The design of the experiment was unbalanced, and only one control treatment was used (see Table 1).

Effect of small Monoporeia affinis on survival of postlarval Macoma balthica. This experiment tested whether juvenile $M$. affinis can reduce the survival of $M$. balthica postlarvae. There were 2 treatments, each with $400 \mathrm{M}$. balthica spat per aquarium $\left(38500 \mathrm{~m}^{-2}\right.$, length $334 \pm 3 \mu \mathrm{m}$ ), one of which received $100 \mathrm{amphi}-$ pods per aquarium $\left(9600 \mathrm{~m}^{-2}\right.$, length $3.6 \pm 0.1 \mathrm{~mm}$, 6 replicates), while the other, including 4 replicates, served as a control.

Effect of adult Pontoporeia femorata on survival of postlarval Macoma balthica. This experiment tested whether adult $6.5 \pm 0.1 \mathrm{~mm}$ long $P$. femorata kill juvenile bivalves. Three amphipods (2300 P. femorata $\mathrm{m}^{-2}$ ) were added to each of 10 vials containing 25 juvenile $M$. balthica (19200 $\mathrm{m}^{-2}$, length $\left.312 \pm 5 \mu \mathrm{m}\right)$. Ten vials without $P$. femorata served as controls.

Final measurements. At the termination of the experiments, the sediment was sieved through a $100 \mu \mathrm{m}$ mesh, and recovered specimens were preserved in $4 \%$ buffered formalin, stained with Rose Bengal. The maximum shell-length of Macoma balthica and amphipod length (straightened out individuals, from the tip of the rostrum to end of the last urosome segment) were measured with an image analyser.

\section{RESULTS}

\section{Functional response of Monoporeia affinis to Macoma balthica postlarvae}

The number of dead Macoma balthica increased with increasing postlarval density in the range tested (Table 1). Considering the control mortality, an average of only 3 postlarvae were killed at the lowest density offered, as compared to 1000 at the highest density. When expressed as the proportion dying during the experiment, the average prey loss rose from 32 $\pm 5 \%$ at the lowest density to $82 \pm 2 \%$ at the highest, as compared to $20 \pm 3 \%$ in the control (Fig. 1). The proportion of postlarvae killed increased significantly with prey density (ANOVA, $F_{6.23}=3,33, p>0.01$ ), indicating a type III-like functional response. The functional response described by the type III equation $y=$ $3718.6 x^{2} /\left(x^{2}+6.425 \times 10^{10}\right)$ gave a better fit $(r=0.99)$ (Fig. 2), than did the type Il equation $y=1.036 \times 10^{7} x$ ) $\left(x+1.579 \times 10^{9}\right)(r=0.93)$, and the correlation coeffi- 
Table 1 Functional response of Monoporeia affinis in the presence of Macoma balthica (initial length $337 \pm 6 \mu m$ ). Forty $M$. affinis per aquarium were added initially (initial length $6.8 \pm 0.1 \mathrm{~mm}$ ). Mean \pm standard error of mean values are shown

\begin{tabular}{|c|c|c|c|c|c|c|c|c|}
\hline & \multicolumn{8}{|c|}{ Treatment (no. of $M$. balthica added per aquarium) } \\
\hline & Control, 400 & 25 & 50 & 100 & 200 & 400 & 800 & 1600 \\
\hline \multicolumn{9}{|l|}{ M. balthica } \\
\hline No. surviving per aquarium & $320 \pm 17$ & $17 \pm 1$ & $31 \pm 3$ & $64 \pm 7$ & $115 \pm 5$ & $196 \pm 22$ & $375 \pm 11$ & $283 \pm 28$ \\
\hline$\%$ surviving & 80 & 68 & 62 & 64 & 58 & 49 & 47 & 18 \\
\hline No. killed per amphipod ${ }^{a}$ & - & $0.08 \pm 0.03$ & $0.24 \pm 0.06$ & $0.44 \pm 0.17$ & $1.2 \pm 0.1$ & $3.1 \pm 0.6$ & $6.6 \pm 0.3$ & $25 \pm 1$ \\
\hline Final length $(\mu \mathrm{m})$ & $336 \pm 3$ & $338 \pm 4$ & $350 \pm 9$ & $354 \pm 9$ & $352 \pm 3$ & $345 \pm 4$ & $348 \pm 12$ & $360 \pm 3$ \\
\hline Length increase $(\mu \mathrm{m})$ & 0 & 1 & 13 & 17 & 15 & 8 & 9 & 23 \\
\hline \multicolumn{9}{|l|}{ M. affinis } \\
\hline No. surviving per aquarium & & $39 \pm 1$ & $39 \pm 1$ & $34 \pm 4$ & $37 \pm 3$ & $39 \pm 1$ & 40 & $40 \pm 1$ \\
\hline Final length (mm) & & $6.9 \pm 0.1$ & $6.8 \pm 0.1$ & $7.0 \pm 0.1$ & $7.0 \pm 0.1$ & $6.7 \pm 0.1$ & $6.9 \pm 0.1$ & $6.8 \pm 0.1$ \\
\hline No. of replicates per treatmen & 5 & 6 & 6 & 4 & 4 & 6 & 2 & 2 \\
\hline
\end{tabular}

cients ( $\mathrm{r}$ ) were significantly different (correlation coefficient test). Independent of $M$. balthica density, 1 to $10 \%$ of the shells recovered were empty. The mean length of $M$. balthica did not change significantly during the experiment, and no significant length differences were detected among treatments (ANOVA, $F_{8,30}=1.41, p>0.22$ ) (Table 1). Monoporeia affinis survival averaged $97 \%$.

\section{Effect of small Monoporeia affinis on survival of postlarval Macoma balthica}

Juvenile amphipods had a strong impact on survival of newly settled Macoma balthica, with a survival of only $32 \%$ over $15 \mathrm{~d}$, whereas almost all (99\%) control bivalves survived (ANOVA, $F_{1,8}=222$, $p<0.0001$ ). Surviving bivalves in the amphipod treatment were significantly longer (mean $361 \pm$ $5 \mu \mathrm{m}$ ) than those added at the start of the experiment (mean $334 \pm 3 \mu \mathrm{m}$ ), and also longer than control bivalves (mean $340 \pm 3 \mu \mathrm{m}$ ) (ANOVA, $F_{213}=13, p<0.0007$; Tukey test, $p<0.05$ ), which did not increase significantly in length during the experiment (Tukey test, $p>0.05$ ). However, maximum sizes of the bivalves did not differ between control and amphipod treatments (ANOVA, $F_{1, B}=0.99, \mathrm{p}>0.34$ ), and no significant difference in the proportion of bivalves that reached a length of $>400 \mu \mathrm{m}$ was indicated (ANOVA, $F_{1,8}=4.72, \mathrm{p}>0.06$ ). Bivalve mortality rate per amphipod (number of amphipods taken as average of initial number and number surviving) per day was $0.19 \pm 0.01$. Surviving Monoporeia affinis (88\%) were $3.7 \pm 0.1$ mm long, which was not significantly different from their length at the start of the experiment $(3.6 \pm 0.1 \mathrm{~mm})$ (ANOVA, $\left.F_{1.9}=3.09, p>0.11\right)$.

\section{Effect of adult Pontoporeia femorata on survival of postlarval Macoma balthica}

Pontoporeia femorata of $6.6 \mathrm{~mm}$ length significantly reduced bivalve survival, from $93 \pm 3 \%$ in the control, to $78 \pm 3 \%$ in the presence of $P$. femorata (ANOVA, $\left.F_{1,18}=11.4, p<0.004\right)$; the mortality rate of bivalves per amphipod (average number of amphipods calculated as above) per day was $0.10 \pm 0.01$. All but one amphipod survived. We assume that the increased bivalve mortality was due to predation, since pieces of crushed shell were found when sieving the amphipod treatment sediment, but not in the sieve residues from the control treatment. Surviving bivalves were significantly longer than those initially added (ANOVA,

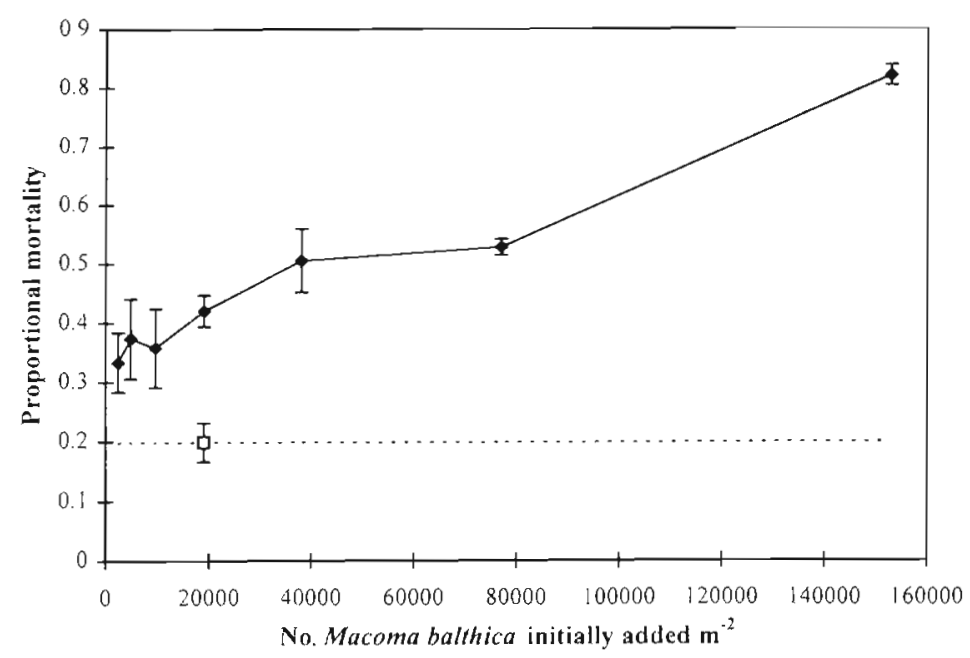

Fig. 1 Macoma balthica. Proportional mortality due to predation by Monoporeia affinis at 7 different postlarval densities over the entire experiment (15 d). ( $\bullet$ Mean proportional mortality at each density, () mean proportional mortality in the control. Error bars represent the standard error of the mean. (...) Assumed mean proportional control mortality for the entire experiment 


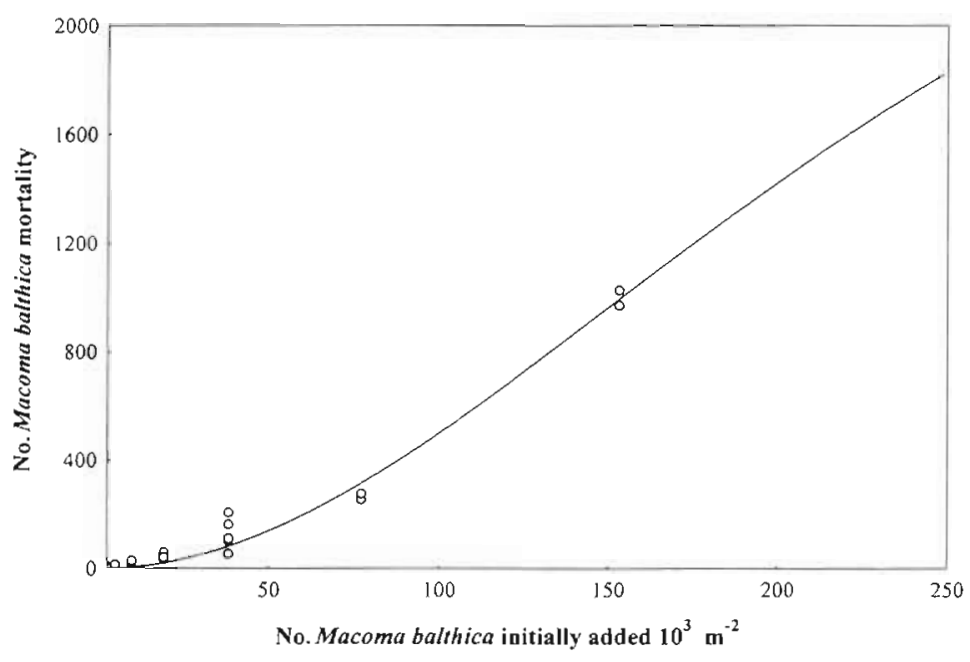

Fig. 2. Functional response of Monoporeia affinis to 6 different densities of Macoma balthica postlarvae. The fitted curve is from the type III functional response model described by Real (1979)

$F_{2,23}=167, \mathrm{p}<0.0001 ;$ Tukey test, $\left.\mathrm{p}<0.05\right)$, but no difference between control $(400 \pm 3 \mu \mathrm{m})$ and amphipod $(394 \pm 3 \mu \mathrm{m})$ treatments (Tukey test, $\mathrm{p}>0.05$ ) was found.

\section{DISCUSSION}

Post-settlement mortality of juvenile benthos is caused by permanent and temporary meiofauna (Thorson 1966, Watzin 1986), as well as by macrofauna (Elmgren et al. 1986, Hunt \& Scheibling 1997). Our experiments support and extend the demonstration by Elmgren et al. (1986) of increased mortality of newly settled Macoma balthica in the presence of adult Monoporeia affinis. Furthermore, we show that juvenile $M$. affinis and adult. Pontoporeia femorata also affect the survival of postlarval $M$. balthica.

When species go through ontogenetic transitions, the food items and food sizes consumed change in relation to changes in body size (Berry \& Thomson 1990). Mineral particles ingested by adult Monoporeia affinis and Pontoporeia femorata, and by juvenile $M$. affinis, are predominantly smaller than $10 \mu \mathrm{m}$, although particles as large as $60 \mu \mathrm{m}$ have been found in their guts (Ankar 1977). As did Elmgren et al. (1986), we found pieces of broken bivalve shells in the sieved sediment from the amphipod treatment, but not from the control treatment. We suggest that the soft parts of the bivalves were ingested after the amphipods had broken the postlarval shell.

In the functional response experiment, mortality of Macoma balthica in the presence of Monoporeia affinis increased with increasing densities of $M$. balthica.
Furthermore, the proportion of bivalves dying increased with postlarval density. Although there was a control for survivorship in the absence of amphipods only at one density, it seems unlikely that the increased mortality at high prey densities was caused by negative intraspecific interactions. The postlarvae of $M$. balthica have no means of causing each other direct harm, so any negative interspecific interaction would have to be caused by exploitative competition for resources or chemical changes caused by high densities. The highest density of $M$. balthica postlarvae used represents less than $0.8 \mathrm{~g}$ wet weight biomass $\mathrm{m}^{-2}$, far below the normal biomass of either meiofauna or macrofauna in the sediment, and thus could neither have materially increased competition for resources nor, given that flow-through aquaria were used, could it have caused oxygen deficiency or accumulation of harmful excretory praducts. In reported experiments, control mortality of M. balthica postlarvae was less than $10 \%$ (Elmgren et al. 1986, this study), except in the functional response experiment, in which it was $20 \%$ (this study). In their review, Hunt \& Scheibling (1997) reported no case in which competition for food was important as a cause of early post-settlement mortality in sedimentary environments. We therefore conclude that the significantly lower proportional mortality at low prey densities indicates a positively density-dependent (type III-like) functional response on the part of the amphipod predator.

In our study the 2 highest densities of Macoma balthica offered were higher than recorded from deeper habitats in the study area, where both species involved are found together (Ólafsson \& Elmgren 1997). However, the response curve still did not flatten out and, as we assume that Monoporeia affinis do eat $M$. balthica, this indicated that the capacity of Monoporeia affinis to consume $M$. balthica was not yet saturated. Estimated consumption in the treatment with the highest $M$. balthica density was ca 300 times higher than in the lowest, and consumption rates (estimated after correction for control mortality) ranged from 0.005 to $1.66 \mathrm{M}$. balthica amphipod ${ }^{-1} \mathrm{~d}^{-1}$. With 15 gut fillings a day and with a gut volume of $0.23 \mathrm{~mm}^{3}$ (Elmgren et al. 1986), an $8 \mathrm{~mm} M$. affinis has the gut capacity to eat an estimated ca $500 \mathrm{M}$. balthica postlarvae of $330 \mu \mathrm{m}$ length, with an estimated volume of $0.005 \mathrm{~mm}^{3}$ (extrapolated from length-weight regressions in Ankar \& Elmgren 1976), not considering ingestion of other particles. Thus, assuming a consumption of 1.66 bivalves $\mathrm{d}^{-1}$ at the highest density of $M$. balthica offered (which is equal to the mortality rate at the highest density), the 
consumption rate measured here is less than $1 \%$ of the number the amphipod could theoretically ingest.

Contrary to the beliefs of Segerstråle (1973), juvenile $(0+)$ Monoporeia affinis of $3.6 \mathrm{~mm}$ length clearly have the potential to regulate newly recruited Macoma balthica, just like adult (1+) $M$. affinis (Elmgren et al. 1986). The surviving $M$. balthica in the juvenile amphipod treatment were significantly longer than both those initially added and the survivors in the control treatment. No significant change in $M$. balthica length was found in the adult amphipod treatment in the functional response experiment. The increase in mean length of $M$. balthica in the juvenile amphipod

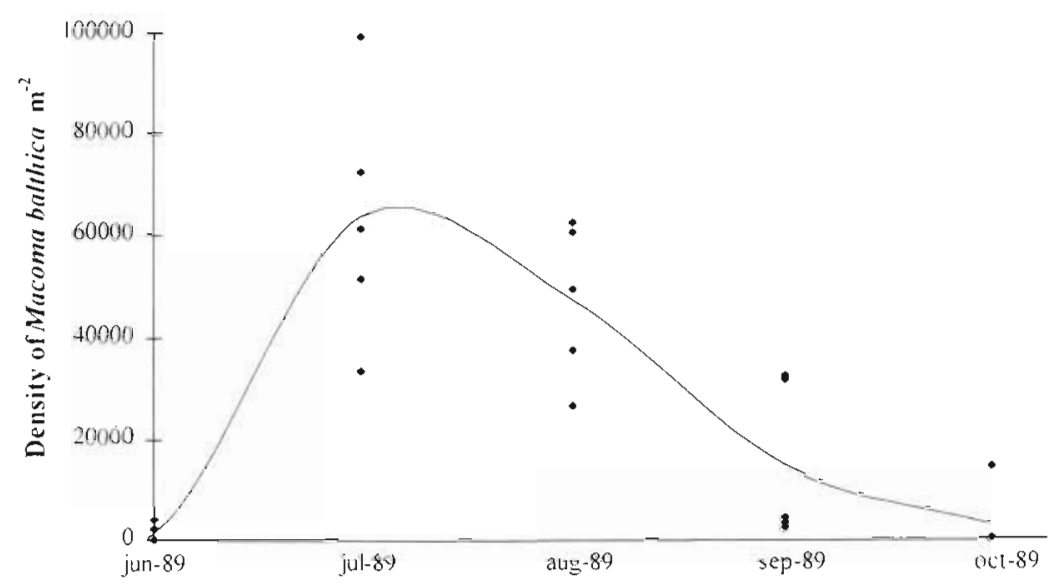

Fig. 3. Macoma balthica. Abundance of juveniles in 1989 at a 37 m deep station in the Askö area, northwestern Baltic proper. Data from E. Olafsson \& R. Elmgren

treatment can be due either to enhanced growth in the presence of juvenile $M$. affinis or to size-selective predation. Juvenile and adult $M$. affinis mix and disturb the surface sediment (Elmgren et al. 1986, van de Bund et al. 1994), and may thus affect the growth rate of juvenile $M$. balthica living there. The largest postlarvae found in both treatments were, however, similar in size. Our results cannot clearly differentiate between the 2 possible explanations, which are not mutually exclusive.

The size at which Macoma balthica becomes too large for juvenile Monoporeia affinis to handle effectively is not accurately known, but $M$. balthica $>1 \mathrm{~mm}$ are no longer susceptible to predation from adult $M$. affinis (Segerstråle 1962). In the Gulf of Finland, eastern Baltic, $M$. balthica grows faster in shallow water, reaching a length of $1 \mathrm{~mm}$ in $6 \mathrm{mo}$ at $3 \mathrm{~m}$ depth, and after 3 yr at $35 \mathrm{~m}$ (Segerstråle 1960). At $10 \mathrm{~m}$ depth in the study area, a size of $1 \mathrm{~mm}$ is reached in less than 6 mo after settling (Ankar 1980), but Elmgren et al. (1983) suggested that at $30 \mathrm{~m}$ depth the postlarvae reached a size of $1 \mathrm{~mm}$ only 1.5 to $2 \mathrm{yr}$ after settling.

Our experiments demonstrated that also Pontoporeia femorata can kill postlarval Macoma balthica. The postlarval mortality rate in the presence of $P$. femorata was 0.10 amphipo $^{-1} \mathrm{~d}^{-1}$ A similar postlarval mortality rate was found in the presence of adult Monoporeia affinis (0.08 amphipod $\left.\mathrm{d}^{-1} \mathrm{~d}^{-1}\right)$ at the same prey density, in spite of adult $M$. affinis having a shorter gut turnover time (mean $=1.5 \mathrm{~h}$ ) than adult $P$. femorata (mean $=2.8 \mathrm{~h})$ and thus almost twice as many gut fillings per day (Lopez \& Elmgren 1989).

Olafsson \& Elmgren (1997) estimated the settling cohort of Macoma balthica spat to ca $65000 \mathrm{~m}^{-2}$ at a $37 \mathrm{~m}$ deep station in the Askö area in July 1989, and by October it had decreased to ca $5000 \mathrm{~m}^{-2}$ (Fig. 3). Amphipod abundance was estimated to be ca $2000 \mathrm{~m}^{-2}$ in October 1989 (C. Hill pers. comm.). Assuming that there was no other mortality, a loss of $60000 \mathrm{M}$. balthica $\mathrm{m}^{-2}$ over $90 \mathrm{~d}$ (July to October) corresponds to a mortality rate of $0.34 \mathrm{M}$. balthica amphipod $\mathrm{d}^{-1} \mathrm{~d}^{-1}$, a mortality rate in between the rates from the $400 \mathrm{M}$. balthica + 40 Monoporeia affinis and $800 \mathrm{M}$. balthica + 40 Monoporeia affinis treatments of the functional response experiment. Elmgren et al. (1986), using the 40:400 abundances of $M$. affinis and $M$. balthica, respectively, and similar sediment, temperature and salinity (their first test), found a mortality rate of 0.22 $M$. balthica amphipod $\mathrm{d}^{-1} \mathrm{~d}^{-1}$, which approximately equals the rate obtained in the functional response 400 M. balthica $+40 \mathrm{M}$. affinis treatment $(0.21 \mathrm{M}$. balthica amphipod ${ }^{-1} \mathrm{~d}^{-1}$ )

Our experiments thus confirm the potential for amphipods to control Macoma balthica recruitment in the field. There were 4 species of macrofauna, other than the amphipods, at the studied station (data from C. Hill pers. comm.). Adult $M$. balthica affect the recruitment of their own offspring at high densities (Bonsdorff et al. 1986), but not at low densities (Ólafsson 1989). The abundance of adult $M$. balthica, at the $37 \mathrm{~m}$ station, was lower than reported by Bonsdorff et al. (1986), and therefore it seems likely that the influence of adult $M$. balthica on small conspecifics was minor. Of the predators, only the isopod Saduria entomon had a significant biomass (about $10 \mathrm{~g}$ wet weight $\mathrm{m}^{-2}$ ), but this was predominantly of individuals of a size that in other experiments did not eat $M$. balthica postlarvae (Ejdung \& Bonsdorff 1992). The polynoid polychaete Harmothoe sarsi had insignificant biomass ( $<1 \mathrm{~g}$ wet weight $\mathrm{m}^{2}$ ), but was at times present in considerable numbers of very small individuals, most small enough to pass through a $1 \mathrm{~mm}$ sieve. H. sarsi is known to eat $M$. balthica, but only as a minor food item (1\% of recorded items; Sarvala 1971). The pria- 
pulid Halicryptus spinulosus had low numbers and insignificant biomass, and is not known to feed on $M$. balthica (Ankar \& Sigvaldadottir 1981), but may negatively affect the survival of small $M$. balthica (Aarnio et al. 1998) at $H$. spinulosus densities 100 -fold larger than. discussed here. There are also predators within the meiofauna (Watzin 1983) and other causes of mortality, e.g. loose-lying algal mats (Bonsdorff 1992). Nevertheless, it seems clear that, while other mortality factors may have made contributions, amphipod predation was the major factor restricting $M$. balthica recruitment at this site, and, by inference, over large areas of the Baltic Sea, as first proposed by Hessle (1924) and Segerstråle (1960). Furthermore, prey populations may be stabilised below a certain prey density threshold in the density-dependent sigmoid functional response (Hassell et al. 1977). Thus, at low density, postlarval $M$. balthica seem to experience a refuge from predation as the predatory mortality risk is much lower than at high density. Although the area studied has low diversity, and some information about interactions among its inhabitants exists (Elmgren et al. 1986, Hill \& Elmgren 1987), physical and biological factors acting over larger areas must be known before large-scale generalisations for Baltic soft bottoms can be made and trusted.

Meiofauna may also affect the diversity and density of recruiting macrofauna, and a conceptual model including juvenile macrofauna-permanent meiofauna interactions was proposed by Bell \& Coull (1980). Further, Watzin (1986) suggested that meiofaunal interactions with juvenile macrofauna should be considered in modelling benthic community organisation. Our experiments indicate that interactions among juvenile macrofauna and temporary meiofauna should also be taken into consideration, as they may affect the structure of benthic communities.

Acknowledgements. B. Stämfors and B. Söderlund gave excellent practical help. The Stockholm Centre for Marine Rescarch provided access to the Askö Laboratory, where the staff were most helpful. C Hill supplied unpublished macrobenthos data. A. Angerbjörn, B. Borg, S. Hansson and M. Tannerfeldt provided useful comments on an earlier draft of the manuscript. Financial support from the Stockholm Centre for Marine Research and the Swedish Academy of Science (Hierta-Retzius foundation) to G.E., and from the Swedish Natural Science Research Council to R.E., is gratefully acknowledged.

\section{LITERATURE CITED}

Aarnio K, Bonsdorff E, Norkko A (1998) Role of Halicruptus spinulosus (Priapulida) in structuring meiofauna and settling macrofauna. Mar Ecol Prog Ser 163:145-153

Ankar S (1977) The soft bottom ecosystem of the northern Baltic proper with special reference to the macrofauna Contrib Askö Lab Univ Stockholm 19:1-62
Ankar S (1980) Growth and production of Macoma balthica (L.) in a northern Baltic soft bottom. Ophelia Suppl 1. $31-48$

Ankar S, Elmgren R (1976) The benthic macro- and meiofauna of the Asko-Landsort area-a stratified random sampling survey. Contrib Askö Lab Univ Stockholm 11: $1-115$

Ankar S, Sigvaldadottir E (1981) On the food composition of Halicryptus spinulosus von Siebold. Ophelia 20:45-51

Baker P, Mann R (1997) The postlarval phase of bivalve molluscs: a review of functional ecology and new records of postlarval drifting of Chesapeake Bay bivalves. Bull Mar Sci 61:409-430

Bell SS, Coull BC (1980) Experimental evidence for a model of juvenile macrofauna-meiofauna interactions. In: Tenore KR, Coull BC (eds) Marine benthic dynamics. University of South Carolina Press, Columbia, p 179-192

Berry AJ, Thomson DR (1990) Changing prey size preferences in the annual cycle of Retusa obtusa (Montagu) (Opisthobranchia) feeding on Hydrobia ulvae (Pennant) (Prosobranchia). J Exp Mar Biol Ecol 141:145-158

Blomqvist S, Lundgren L (1996) A benthic sled for sampling soft bottoms. Helgal Meeresunters 50:453-456

Bonsdorff E (1992) Drifting algae and zoobenthos-effects on settling and community structure. Neth J Sea Res 30 $57-62$

Bonsdorff E, Mattila J, Rönn C, Österman CS (1986) Multidimensional interactions in shallow soft-bottom ecosystems; testing the competitive exclusion principle. Ophelia Suppl $4: 37-44$

Bonsdorff E, Norkko A, Boström C (1995) Recruitment and population maintenance of the bivalve Macoma balthica (L.) -factors affecting settling success and early survival on shallow sandy bottoms. In: Eleftheriou $A$, Ansell AD, Smith CJ (eds) Biology and ecology of shallow coastal waters. Proc 28th Eur Mar Biol Symp, Crete, Greece, 23-28 September, 1993. Olsen and Olsen, Fredensborg, p 253-260

Bousfield EL (1989) Revised morphological relationships within the amphipod genera Pontoporeia and Gammaracanthus and the 'glacial relict' significance of their postglacial distributions. Can J Fish Aquat Sci 46:1714-1725

Caddy JF (1969) Development of mantle organs, feeding, and locomotion in postlarval Macoma balthica (L.) (Lamellibranchiata). Can J Zool 47:609-617

Cederwall H (1977) Annual macrofauna production of a soft bottom in the northern Baltic proper. In: Keegan BF, Céidigh PÓ, Boaden PJS (eds) Biology of benthic organisms. Proc 11th Eur Mar Biol Symp, Galway, Ireland, 5-11 October, 1976. Pergamon Press, Oxford, p 155-164

Cederwall H (1990) Övervakning av mjukbottenfauna i Östersjöns kustområde. Rapport från verksamheten 1989. SNV rapport 3796. ISBN 91-620-3796X. ISSN 0282-7298

Eggleston DB (1990) Behavioural mechanisms underlying variable functional responses of blue crabs, Callinectes sapidus feeding on juvenile oysters, Crassostrea virginica. J Anim Ecol 59:615-630

Ejdung G, Bonsdorff E (1992) Predation on the bivalve Macoma balthica (L.) by the isopod Saduria entomon (L.): laboratory and field experiments. Mar Ecol Prog Ser 88 $207-214$

Elmgren R (1978) Structure and dynamics of Baltic benthos communities, with particular reference to the relationship between macro- and meiofauna. Kiel Meeresforsch 4:1-22

Elmgren R, Ankar A, Marteleur B, Ejdung G (1986) Adult interference with postlarvae in soft sediments: the Pontoporeia-Macoma example. Ecology 67:827-836 
Elmgren R, Hansson S, Larsson U, Sundelin B, Boehm PD (1983) The 'Tsesis' oil spill: acute and long-term impact on the benthos. Mar Biol 73:51-65

Elmgren R, Larsson U (1997) Bottenfauna. In: Elmgren R, Larsson $U$ (eds) Himmerfjärden. Changes in a nutrient enriched coastal ecosystem. Gotab, Stockholm, p 112-117

Hassell MP (1978) The dynamics of arthropod predator-prey systems. Monographs in Population Biology 13. Princeton University Press, Princeton

Hassell MP, Lawton JH, Beddington JR (1977) Sigmoid functional responses by invertebrate predators and parasitoids. J Anim Ecol 46:249-262

Hessle C (1924) Bottenboniteringar i inre Östersjön. Medd K Lantbruksstyrelsen 250:1-52

Hill C, Elmgren R (1987) Vertical distribution in the sediment in the co-occurring benthic amphipods Pontoporeia affinis and $P$. femorata. Oikos 49:221-229

Hill C, Quigley MA, Cavaletto JF, Gordon W (1992) Seasonal changes in lipid content and composition in the benthic amphipods Monoporeia affinis and Pontoporeia femorata. Limnol Oceanogr 37:1280-1289

Holling CS (1959) Some characteristics of simple types of predation and parasitism. Can Entomol 91:385-398

Hunt HL, Scheibling RE (1997) Role of early post-settlement mortality in recruitment of benthic marine invertebrates Mar Ecol Prog Ser 155:269-301

Järvekülg A (1973) Distribution and ecology of local populations of benthic glacial relicts. Oikos Suppl 15:91-97

Lehtonen K (1996) Ecophysiology of the benthic amphipod Monoporeia affinis in an open-sea area of the northern Baltic Sea: seasonal variations in body composition, with bioenergetic considerations. Mar Ecol Prog Ser 143 $87-98$

Lipcius RN, Hines AH (1986) Variable functional responses of a marine predator in dissimilar homogeneous microhabitats. Ecology 67:1361-1371

Lopez G, Elmgren R (1989) Feeding depths and organic absorption for the deposit-feeding benthic amphipods Pontoporeia affinis and Pontoporeia femorata. Limnol Oceanogr 34:982-991

Lopez GR, Levinton JR (1987) Ecology of deposit-feeding animals in marine sediments. Q Rev Biol 62:235-260

Ólafsson EB (1989) Contrasting influences of suspensionfeeding and deposit-feeding populations of Macoma balthica on infaunal recruitment. Mar Ecol Prog Ser 55: $171-179$

Ólafsson E, Elmgren R (1997) Seasonal dynamics of sublittoral meiobenthos in relation to phytoplankton sedimentation in the Baltic Sea. Estuar Coast Shelf Sci 45:149-164

Osman RW, Whitlatch RB (1995) Predation on early ontogenetic life stages and its effect on recruitment into a marine epifaunal community. Mar Ecol Prog Ser 117:111-126

Osman RW, Whitlatch RB, Malatesta RJ (1992) Potential role of micro-predators in determining recruitment into a marine community. Mar Ecol Prog Ser 83:35-43

Editonal responsibility: Otto Kinne (Editor), Oldendorf/Luhe, Germany
Real LA (1979) Ecological determinants of functional response. Ecology 60:481-485

Sarvala J (1971) Ecology of Harmothoe sarsi (Malmgren) (Polychaeta, Polynoidae) in the northern Baltic area. Ann Zool Fenn 8:231-309

Sarvala J (1986) Interannual variation of growth and recruitment in Pontoporeia affinis (Lindström) (Crustacea: Amphipoda) in relation to abundance fluctuations. J Exp Mar Biol Ecol 101:41-59

Sarvala J, Uitto A (1991) Production of the benthic amphipods Pontoporeia affinis and P. femorata in a Baltic archipelago. Ophelia 34:71-90

Segerstrále SG (1960) Investigations on Baltic populations of the bivalve Macoma balthica (L.). Part I. Introduction. Studies on recruitment and its relation to depth in Finnish coastal waters during the period 1922-1959. Age and growth. Commentat Biol Soc Sci Fenn 23:1-72

Segerstråle SG (1962) Investigations on Baltic populations of the bivalve Macoma balthica (L.). Part II. What are the reasons for the periodic failure of recruitment and the scarcity of Macoma in the deeper waters of the inner Baltic? Commentat Biol Soc Sci Fenn 24:1-26

Segerstrale SG (1965) Biotic factors affecting the vertical distribution and abundance of the bivalve, Macoma balthica (L.), in the Baltic Sea. Bot Gothoburgensia 3:195-204

Segerstråle SG (1973) Results of bottom fauna sampling in certain localities in the Tvarminne area (inner Baltic), with special reference to the so-called Macoma-Pontoporeia theory. Commentat Biol Soc Sci Fenn 67:2-12

Thorson G (1966) Some factors influencing the recruitment and establishment of marine benthic communities. Neth J Sea Res 3:267-293

Turunen S, Pekkarinen M (1990) Fatty acid profile of the digestive gland and mantle in the bivalve Macoma balthica. Comp Biochem Physiol 97B:269-273

Uitto A, Sarvala J (1990) Perspectives on the ecological factors regulating Pontoporeia populations in the northern Baltic Sea. Ann Zool Fenn 27:297-301

Uitto A. Sarvala J (1991) Seasonal growth of the benthic amphipods Pontoporeia affinis and $P$. femorata in a Baltic archipelago in relation to environmental factors. Mar Biol 111:237-246

van de Bund WJ, Goedkoop W, Johnson RK (1994) Effects of deposit-feeder activity on bacterial production and abundance in profundal lake sediment. J North Am Benthol Soc 13:532-539

Watzin MC (1983) The effects of meiofauna on settling macrofauna: meiofauna may structure macrofaunal communities. Oecologia 59:163-166

Watzin MC (1986) Larval settlement into marine soft-sediment systems: interactions with the meiofauna. J Exp Mar Biol Ecol 98:65-113

Woodin SA, Lindsay SM, Wethey DS (1995) Process-specific recruitment cues in marine sedimentary systems. Biol Bull (Woods Hole) 189:49-58

Submitted: December 29, 1997; Accepted: May 11, 1998

Proofs received from author(s): June 26, 1998 